\title{
Impact of Type and Dose of Recombinant Human Follicle Stimulating Hormone on Embryos Production in Dairy Cows and Their Relationship with AMH Concentration
}

\author{
Kamel Mohammed ${ }^{1, ~ *, ~ G a m a l ~ D a r w i s h ~}{ }^{1}$, Ragab Dohreig ${ }^{1}$, Ahmed Mahmoud ${ }^{2}$, Zaher Rawash $^{1}$, \\ Abdel Khaleik Nassra ${ }^{1}$, Magdy Badr ${ }^{1}$, Ayman Hassan ${ }^{3}$, Sayed Essawy \\ ${ }^{1}$ Artificial Insemination and Embryo Transfer Department, Animal Reproduction Research Institute (ARRI), Giza, Egypt \\ ${ }^{2}$ Cattle Production Department, Armed Force Farm, Fayoum, Egypt \\ ${ }^{3}$ Animal Biology Department, Animal Reproduction Research Institute (ARRI), Giza, Egypt
}

\author{
Email address: \\ Kamel14@hotmail.com (K. Mohammed) \\ ${ }^{*}$ Corresponding author
}

\section{To cite this article:}

Kamel Mohammed, Gamal Darwish, Ragab Dohreig, Ahmed Mahmoud, Zaher Rawash, Abdel Khaleik Nassra, Magdy Badr, Ayman Hassan, Sayed Essawy. Impact of Type and Dose of Recombinant Human Follicle Stimulating Hormone on Embryos Production in Dairy Cows and Their Relationship with AMH Concentration. Animal and Veterinary Sciences. Special Issue: Application of Advanced Reproductive Technologies for Production Transferable Embryos. Vol. 7, No. 5, 2019, pp. 104-112. doi: 10.11648/j.avs.20190705.11

Received: August 21, 2019; Accepted: September 4, 2019; Published: November 13, 2019

\begin{abstract}
The study was investigated to compare the effectiveness of Folltropin and two products (Fostimon and Menogon) of a recombinant human follicle stimulating hormone ( $\mathrm{rhFH}$ ) on ovarian super-stimulation and embryo production in dairy Holstein cows. Two different doses for each super-ovulatory product were investigated. The relationship between the levels of Anti-Mullerian Hormone (AMH) in the blood serum before super-stimulation initiation and ovarian response and embryos production were also evaluated. At random stage of the estrus cycle, the donor cows were received intra-vaginal controlled internal drug release device (CIDR) and injected with $100 \mu \mathrm{g}$ of gonadotropin-releasing hormone (GnRH). On fourth day of CIDR insertion, cows were divided according to the product types of superovulatory hormones into three equal main groups. According to hormonal dose, each main group was re-divided into two equally sub-groups; low and high dose. Superovulatory hormones was injected IM as decreasing doses; $40 \%, 30 \%, 20 \%$ and $10 \%$ of the total dose twice daily for 4 days. On day 7, CIDRs were removed and each cow received 2 doses of $\mathrm{PGF}_{2} \alpha$ with $12 \mathrm{hr}$ interval. Based upon heat detection, donor's cows were inseminated with frozen semen three times 8-10hrs interval and concurrent with $100 \mu \mathrm{g}$ GnRH injection at first insemination. Non-surgical embryos recovery was performed on day's 7-8 post insemination and ovarian super-stimulation was checked using sonography to estimate ovarian response. Recovered embryos were morphologically evaluated as grades. Twelve embryos collected from Menogon donors group were transferred to six recipient's cows. The mean numbers of CL, recovered embryo/ova, fertilized ova and transferable embryos are significantly $(\mathrm{P}<0.01)$ higher in Folltropin and Menogon treated cows than Fostimon group. Donor cows treated with high doses of Folltropin and Menogon showed higher means for transferable and freezable embryos. Three recipients (50\%) who received embryos appeared pregnant and one of them born calf. Significant positive correlations were reported between $\mathrm{AMH}$ on one side and CL, total ovarian response, transferable and freezable embryos on the other side, and cows having $\mathrm{AMH} \geq 230 \mathrm{ng} / \mathrm{L}$ exhibited significant higher means. In conclusion: Menogon can be used as rhFSH for embryos production with transferable quality. AMH can be used as indicator to helpful select cow's candidates as donors. More studies are needed using Fostimon accompanied with different levels of LH.
\end{abstract}

Keywords: Dairy Cows, Multiple Ovulation and Embryo Transfer (MOET), Recombinant Human Follicle Stimulating Hormone (rhFSH), Anti-müllerian Hormone (AMH) 


\section{Introduction}

Multiple ovulation and embryo transfer (MOET) is one of reproductive biotechnologies, revolutions that opened avenues for strengthening the genetic improvement of animal production [1]. Induction of ovarian super-stimulation and subsequent production of transferable embryos with high quality are widely variables among donor cows within herd even for the same breeds [2, 3]. Therefore, the superovulatory response fortuity is still represents obstacles facing the efficiency and profitability of MOET program during practical application [4]. These variability have been attributed to gonadotrophin preparation with differences LH:FSH activities [5-9] and its protocols for treatments [10, 11]. In addition, antral follicle count and AMH level are contributed to these variability's [12, 13]. Selection of candidate donor's cows for embryos production based on AMH level will reduce this variability [14]. AMH secreted by the granulosa cells of the ovary and characteristic for each animal on a long term period [15] and providing highly accurate information on the ovarian follicular pool and follicular responsiveness [16]. It is suggested that intrinsic between animal differences in AMH result in marked animalto-animal variations in the magnitude of the ovarian superstimulation response. So, recently, AMH concentrations in the blood of candidate donors are used as a reliable predictive marker with high probability to produce a reasonable number of transferable embryos $[17,18]$. The present study focused to compare the effectiveness of three commercial preparations of FSH with different LH activity on ovarian super-stimulation and embryo recovery in dairy cows. These products include Folltropin; contains highly purified extract of porcine pituitary glands with low LH:FSH, Fostimon; contains Urofollitropin which is a highly purified FSH, Menogon; contains Menotropin which is human menopausal gonadotropin (HMG) corresponding to equal ratio of FSH:LH. The last two products are a new preparation of a recombinant human follicle stimulating hormone (rhFSH) used for dairy cows. Two different doses of these products are applied for MOET program in this study. The relationship between circulating AMH concentrations and ovarian response and its outputs of embryos production were also investigated as other objective.

\section{Materials and Methods}

\subsection{Animal's Management and Handling}

A total of 36 cyclic dairy Holstein cows from first to three lactations and at least 60 days postpartum period were used as donors for ovarian super-stimulation and embryos production. The live body weights and ages were $320-460 \mathrm{~kg}$ and 2-5.5 years, respectively. The study was carried out at two farms; private farm (Al-Awadi dairy farm) located at Alexandria desert road and cattle production farm of armed force farm. Donor cows were kept in conditions of management depending on the system applied for each farm without any interventions from the research team. To avoid the effects of phenotypic differences between animals, it was taken into account that each hormonal treatment should be representative for animals. Moreover, all processes related to donor cows treatments such as artificial insemination; ovarian response evaluation, embryos recovery and evaluation were responsibility of the researchers' team.

\subsection{Principle Design of the Study}

The donors cows were divided according to the product types of superovulatory hormones into three equal $(\mathrm{n}=12)$ main groups (A, B and C). Each main group was re-divided according to the dose of superovulatory hormones into two equally ( $\mathrm{n}=6$ ) sub-groups; 1 (low dose) and 2 (high dose). Just before the initiation superovulatory treatment, $4 \mathrm{~mL}$ blood samples from jugular vein were collected to determine the levels of AMH in the blood serum.

\subsection{Estrus Synchronization and Superovulatory Protocols}

Select Synch + CIDR protocols were used for estrus synchronization according to Cliff Lamb [19] and Larson [20]. On a random day of estrus cycle (day 0 ), all donor cows were received intra-vaginal controlled internal drug release device (CIDR-containing $1.38 \mathrm{~g}$ progesterone, Pfizer Animal Health Ltd, New Zeland), and at the same time injected IM with $100 \mu \mathrm{g}$ of GnRH (Cystorelin; Gonadorelin, Boehringer Ingelheim Animal Health USA) as first dose. Donor cows of group A were superovulated using Folltropin (National Institutes of Health, USA) with a total dose of $300 \mathrm{mg}$ (group A1; low dose) and 400mg (group A2; high dose). Folltropin was injected IM as decreasing doses; $40 \%, 30 \%, 20 \%$ and $10 \%$ of the total dose twice daily for 4 days $(60,60,45,45,30,30,15$ and $15 \mathrm{mg}$ for group A1; and 80, 80, 60, 60, 40, 40, 20 and $20 \mathrm{mg}$ for group A2). The schedule of superovulatory hormone injections of the other two groups (B and C) were applied as group A, but using Fostimon (Laboratoires Genevrier S. A., France) for group B, and Menogon (Ferring Pharmaceuticals Ltd. GmbH, Germany) for group C. A total dose of 600IU as low dose $(120,120,90,90,60,60,30$ and 30 IU for groups B1 and C1) and $900 \mathrm{IU}$ as high dose (180, 180, 135, 135, 90, 90, 45 and $45 \mathrm{IU}$ for groups B2 and $\mathrm{C} 2$ ). On day 7, CIDRs were removed and each cow received 2 doses of 500 $\mathrm{\mu g}$ Cloprostenol $\left(\mathrm{PGF}_{2} \alpha\right.$, Estrumate; coopers, GmbH, Germany) with $12 \mathrm{hr}$ interval. Based upon heat detection, synchronized cows were inseminated three times $8-10 \mathrm{hrs}$ interval with 2 straws of high quality frozen semen per insemination and concurrent with second dose of $\mathrm{GnRH}(100 \mu \mathrm{g})$ at first insemination.

\subsection{Embryo Recovery and Ovarian Super-stimulation Evaluation}

Non-surgical embryo recovery was performed on day's 7-8 post insemination, using a Foley catheter and Dulbecco's phosphate buffer saline (D-PBS) as flushing medium. At the beginning of flushing the ovaries of donor cows were checked using sonography examinations to estimate the 
number of corpora lutea (CL) and follicles (F). Recovered embryos were morphologically evaluated according to International Embryo Transfer Society criteria [21] and Bo [22]. Collected embryos were classified according to its quality into transferable embryos of grades 1 (excellent and good) \& 2 (regular and poor). Grade 1 embryos are considered freezable embryos.

\subsection{Recipient's Preparation to Receive Embryos}

Twelve embryos (6 grade 1 and 6 grade 2 ) collected from Menogon treated donor cows were transferred to six recipient's cows. Synchronization of estrus for recipient was done like that of donors. On day 7 of estrus cycle, 2 embryos (one grade 1 and other grade 2) were transferred nonsurgically to the apex of the uterine horn ipsilateral to CL. Pregnancy was presumed when recipient cows not return to estrus up to 25 days of transfer and confirmed by ultrasound scanning at 45 days of gestation.

\subsection{Anti-Mullerian Hormone Assay}

The collected blood samples were centrifuged at 3000rpm for $15 \mathrm{~min}$., and the serum were separated and stored at $-20^{\circ} \mathrm{C}$ until AMH assay. One day before assay, the serum samples were removed from frozen storage and thawed over night at $4^{\circ} \mathrm{C}$. Bovine AMH enzyme linked immune sorbent assay kit (GenAsia Biotech Co., Ltd.) was used to determine AMH concentration (ng/L). Serum samples were analyzed for $\mathrm{AMH}$ following the outlined instructions in the prospectus kit. The AMH assay had range $2 \mathrm{ng} / \mathrm{L}$ to $700 \mathrm{ng} / \mathrm{L}$ and analytical sensitivity $1.06 \mathrm{ng} / \mathrm{L}$. The intra-assay and interassay coefficients of variation $(\mathrm{CV}=\mathrm{SD} /$ mean $\times 100)$ were $<10 \%$ and $<12 \%$, respectively.

\subsection{Statistical Analysis}

The obtained data were analyzed using SPSS version 16.0 (Statistical Package for Social Sciences) software for windows. The effects of the studied factors on the different parameters of ovarian response and production of embryos were statistically analyzed using ANOVA. General Linear Model (GLM) factorial procedure followed by post Hoc and Duncan tests were used for means comparison with significance level at $\mathrm{P}<0.01$ or 0.05 . The relationships between AMH concentration and ovarian response parameters (CL and total ovarian response) and embryo production (transferable and freezable embryos) were measured using Pearson correlations coefficients.

Table 1. Influence of product types of superovulatory hormone on the ovarian super-stimulation and embryos production (means \pm SE).

\begin{tabular}{llll}
\hline \multirow{2}{*}{ Items } & \multicolumn{3}{l}{ Product types of superovulatory hormones } \\
\cline { 2 - 4 } & Folltropin (Group A) & Fostimon (Group B) \\
\hline Corpora lutea (CL) & $8.92 \pm 0.48^{\mathrm{a}}$ & $3.58 \pm 0.29^{\mathrm{b}}$ & Menogon (Group C) \\
Unovulated follicles (UOF) & $2.08 \pm 0.54^{\mathrm{b}}$ & $8.83 \pm 0.80^{\mathrm{a}}$ & $7.75 \pm 0.49^{\mathrm{a}}$ \\
Total ovarian response & $11.00 \pm 0.86^{\mathrm{ab}}$ & $12.42 \pm 0.64^{\mathrm{a}}$ & $1.67 \pm 0.43^{\mathrm{b}}$ \\
Total embryo/ova & $5.42 \pm 0.45^{\mathrm{a}}$ & $1.75 \pm 0.33^{\mathrm{b}}$ & $1.08 \pm 0.26^{\mathrm{b}}$ \\
Fertilized ova & $4.42 \pm 0.31^{\mathrm{a}}$ & $0.83 \pm 0.17^{\mathrm{b}}$ & $5.17 \pm 0.44^{\mathrm{a}}$ \\
Transferable embryos (TE) & $3.83 \pm 0.27^{\mathrm{a}}$ & $0.50 \pm 0.15^{\mathrm{b}}$ & $4.17 \pm 0.42^{\mathrm{a}}$ \\
Grade 1 TE (Freezable embryos) & $2.42 \pm 0.19^{\mathrm{a}}$ & $0.33 \pm 0.14^{\mathrm{b}}$ & $3.67 \pm 0.40^{\mathrm{a}}$ \\
Grade 2 TE & $1.42 \pm 0.15^{\mathrm{a}}$ & & $2.58 \pm 0.36^{\mathrm{a}}$ \\
\hline
\end{tabular}

Means in the same raw with different superscripts are differ significantly at $\mathrm{P}<0.01$.

Table 2. Effect of superovulatory hormonal doses on the ovarian super-stimulation and embryo production (means \pm SE).

\begin{tabular}{|c|c|c|c|c|c|c|}
\hline \multirow{2}{*}{ Superovulatory hormones and doses } & \multicolumn{2}{|c|}{ Folltropin (Group A) } & \multicolumn{2}{|c|}{ Fostimon (Group B) } & \multicolumn{2}{|c|}{ Menogon (Group C) } \\
\hline & 1 (300 mg) & $2(400 \mathrm{mg})$ & $1(600 \mathrm{IU})$ & $2(900$ IU) & $1(600 \mathrm{IU})$ & 2 (900 IU) \\
\hline Corpora lutea (CL) & $8.00 \pm 0.44^{\mathrm{b}}$ & $9.83 \pm 0.70^{\mathrm{a}}$ & $4.00 \pm 0.45$ & $3.17 \pm 0.31$ & $7.33 \pm 0.80$ & $8.17 \pm 0.60$ \\
\hline Unovulated follicles (UOF) & $2.00 \pm 0.82$ & $2.17 \pm 0.79$ & $6.83 \pm 0.65^{\mathrm{b}}$ & $10.83 \pm 0.87^{\mathrm{a}}$ & $1.50 \pm 0.72$ & $1.83 \pm 0.54$ \\
\hline Total ovarian response & $10.00 \pm 1.03$ & $12.00 \pm 1.34$ & $10.83 \pm 0.54^{\mathrm{b}}$ & $14.00 \pm 0.73^{\mathrm{a}}$ & $8.83 \pm 1.22$ & $10.00 \pm 1.13$ \\
\hline Total embryo/ova & $4.33 \pm 0.33^{b}$ & $6.50 \pm 0.56^{\mathrm{a}}$ & $2.17 \pm 0.54$ & $1.33 \pm 0.33$ & $4.67 \pm 0.62$ & $5.67 \pm 0.62$ \\
\hline Fertilized ova & $4.00 \pm 0.36$ & $4.83 \pm 0.48$ & $1.33 \pm 04$ & $0.83 \pm 0.31$ & $3.50 \pm 0.67$ & $4.83 \pm 0.40$ \\
\hline Transferable embryos (TE) & $3.50 \pm 0.22$ & $4.17 \pm 0.48$ & $1.00 \pm 0.26$ & $0.67 \pm 0.21$ & $2.83 \pm 0.54^{\mathrm{b}}$ & $4.50 \pm 0.34^{\mathrm{a}}$ \\
\hline Grade 1 TE (Freezable embryos) & $2.17 \pm 0.17$ & $2.67 \pm 0.33$ & $0.50 \pm 0.22$ & $0.50 \pm 0.22$ & $1.83 \pm 0.54^{\mathrm{b}}$ & $3.33 \pm 0.21^{\mathrm{a}}$ \\
\hline Grade $2 \mathrm{TE}$ & $1.33 \pm 0.21$ & $1.50 \pm 0.22$ & $0.50 \pm 0.22$ & $0.17 \pm 0.17$ & $1.00 \pm 0.00$ & $1.17 \pm 0.31$ \\
\hline
\end{tabular}

Means of same superovulatory hormone in the same raw with different superscripts are differ significantly at $\mathrm{P}<0.05$.

Table 3. ANOVA showing the effects of superovulatory hormone and their interactions on the ovarian response and embryo production.

\begin{tabular}{|c|c|c|c|c|c|c|c|c|c|}
\hline \multirow{2}{*}{ Source of variation } & \multirow{2}{*}{ df } & \multicolumn{2}{|c|}{ Corpora lutea } & \multicolumn{2}{|c|}{ Total ovarian response } & \multicolumn{2}{|c|}{ Transferable embryos } & \multicolumn{2}{|c|}{ Freezable embryos (Grade 1) } \\
\hline & & MS & $\mathbf{F}$ & MS & $\mathbf{F}$ & MS & $\mathbf{F}$ & MS & $\mathbf{F}$ \\
\hline Superovulatory hormones (SH) & 2 & 94.33 & $47.30^{* *}$ & 27.03 & $4.19^{*}$ & 34.11 & $42.64^{* *}$ & 16.08 & $27.84^{* *}$ \\
\hline Doses of SH (D) & 1 & 3.36 & $1.69^{\mathrm{ns}}$ & 40.11 & $6.21^{*}$ & 4.00 & $5.00^{*}$ & 4.00 & $6.92^{* *}$ \\
\hline Interactions & & & & & & & & & \\
\hline $\mathrm{SH} \times \mathrm{D}$ & 2 & 5.44 & $2.73^{\mathrm{ns}}$ & 3.03 & $0.47^{\mathrm{ns}}$ & 3.00 & $3.75^{*}$ & 1.75 & $3.03^{\text {ns }}$ \\
\hline Error & 30 & 1.99 & & 6.46 & & 0.80 & & 0.58 & \\
\hline
\end{tabular}

* $\mathrm{P}<0.05 ; * * \mathrm{P}<0.01, \mathrm{~ns}=$ no significant. 


\section{Results}

The effect of superovulatory hormonal types on ovarian super-stimulation and embryo production are shown in table 1. The mean numbers of CL, total embryo/ova, fertilized ova, freezable and transferable embryos are significantly $(\mathrm{P}<0.01)$ higher in Folltropin and Menogon treated animal groups than Fostimon group. Contrary, the mean number of unovulated follicles was significant higher $(\mathrm{P}<0.01)$ in Fostimon group than other 2 groups. As shown in table 2, the donor cows injected with high dose of Folltropin showed higher significant $(\mathrm{P}<0.05)$ means for $\mathrm{CL}(9.83 \pm 0.70$ vs $8.00 \pm 0.44)$ and total embryo/ova ( $6.50 \pm 0.56$ vs $4.33 \pm 0.33)$ than low dose, whereas, donors treated with a high dose of Menogon showed a significant higher $(\mathrm{P}<0.05)$ means of transferable (4.50 \pm 0.34 vs $2.83 \pm 0.54)$ and freezable embryos $(3.33 \pm 0.21$ vs $1.83 \pm 0.54)$. However, cows treated with Fostimon showed no significant differences between 2 doses for these parameters (table 2). Generally, the interactions between superovulatory hormones and its doses had a significant $(\mathrm{P}<0.05)$ effects on transferable embryos and no further effects on the other parameters (table 3 ).

Three out six recipients received embryos were considered pregnant where they did not return to estrus up to 25 days of transfer. Two pregnant recipient cows showed turbid vaginal discharge mixed with pus between days 30 to 40 of transfer. One recipient cow confirmed pregnant at day 45 of transfer and the gestation period was full termed and one healthy calf was born.

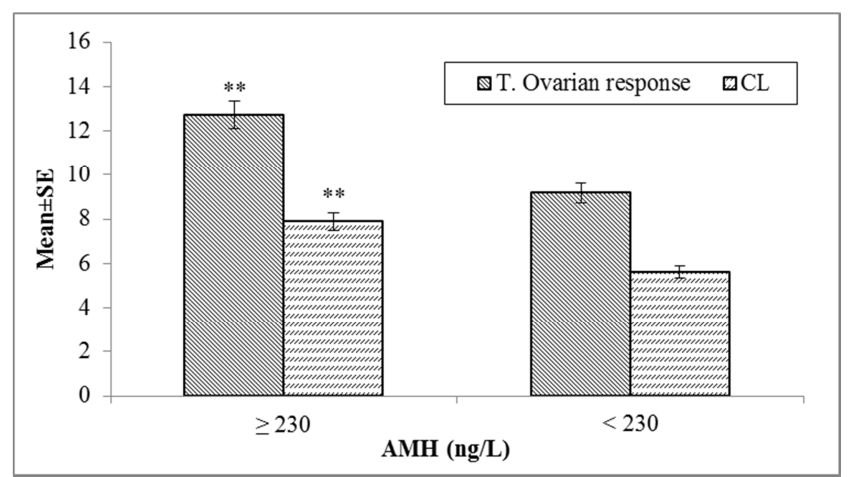

Figure 1. Ovarian response related to AMH concentrations at day 0 before initiation of superovulatory treatment. $* * P<0.01$.

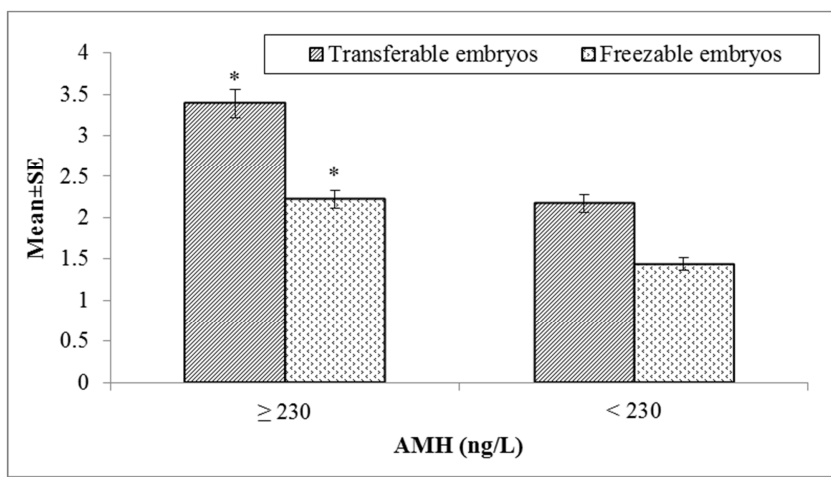

Figure 2. Transferable and freezable embryos related to $A M H$ concentrations at day 0 before initiation superovulatory treatment. $* P<0.05$.
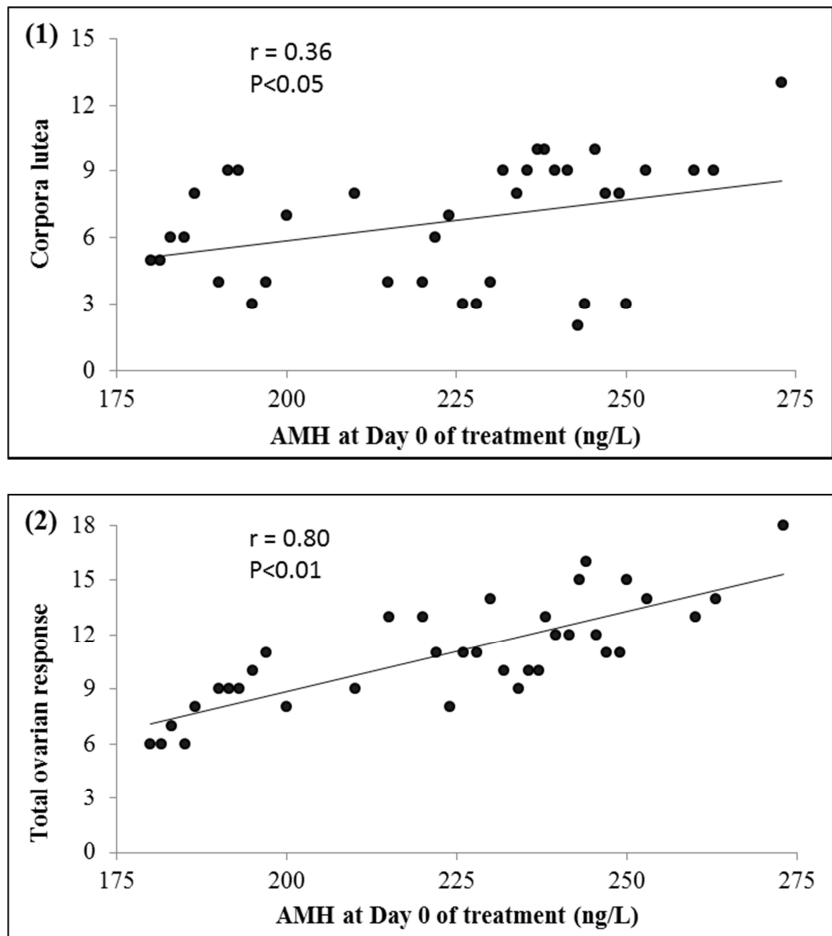

Figure 3. Correlations between AMH concentrations in the blood serum of Holstein dairy cows $(n=36)$ at day 0 of superovulatory treatment and ovarian response. The data represent the relationships between $A M H$ concentration $(\mathrm{ng} / \mathrm{L})$ and number of corpora lutea (1) and total ovarian response (2).
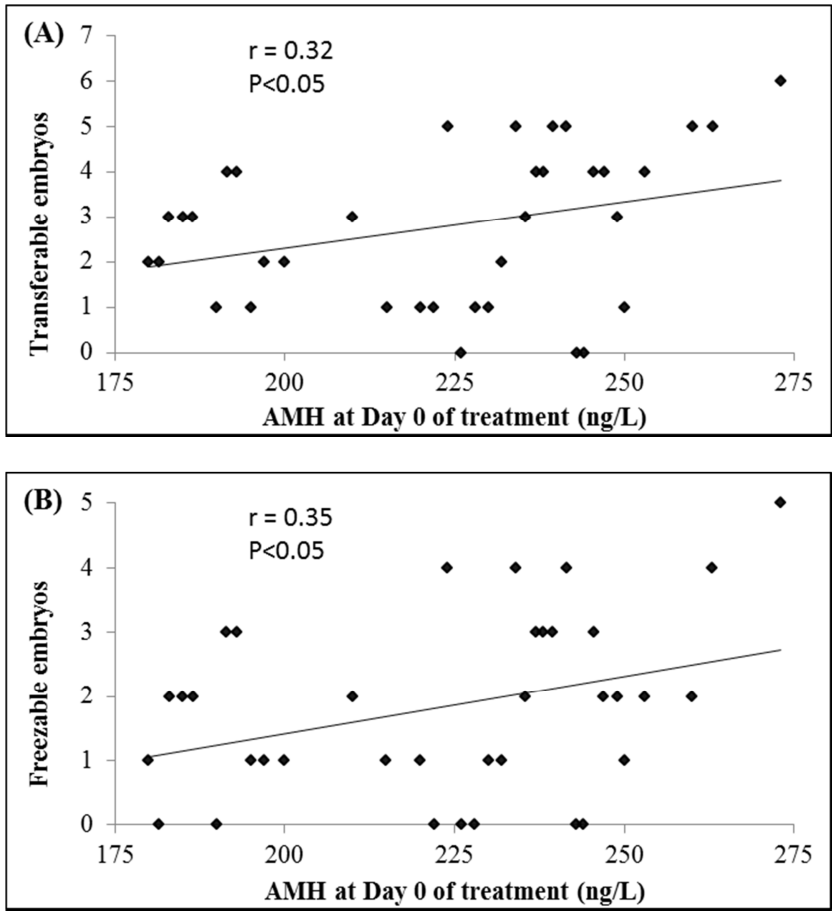

Figure 4. Correlations between AMH concentrations in the blood serum of Holstein dairy cows $(n=36)$ at day 0 of superovulatory treatment and embryo production. The data represent the relationships between $A M H$ concentration $(n g / L)$ and number of transferable embryos $(A)$ and number of freezable embryos $(B)$. 
According to AMH concentrations, the treated donor's cows were divided into two groups: $\geq 230 \mathrm{ng} / \mathrm{L}(\mathrm{n}=18)$ and $<230 \mathrm{ng} / \mathrm{L} \quad(\mathrm{n}=18)$. Interestingly, the means of the total ovarian response and $\mathrm{CL}$ were significant $(\mathrm{P}<0.01)$ higher for cows group having AMH concentration $\geq 230 \mathrm{ng} / \mathrm{L}$ (figure 1). Similarly, the means of transferable and freezable embryos were significant higher $(\mathrm{P}<0.05)$ for cows group which had $\mathrm{AMH}$ concentrations $\geq 230 \mathrm{ng} / \mathrm{L}$ (figure 2 ).

Generally, the correlations between AMH concentrations and ovarian response were significant positive for $\mathrm{CL}$ $(\mathrm{r}=0.36 ; \mathrm{P}<0.05)$ and total ovarian response $(\mathrm{r}=0.80 ; \mathrm{P}<0.01)$ (figure 3), transferable $(\mathrm{r}=0.32 ; \mathrm{P}<0.05)$ and freezable embryos $(\mathrm{r}=0.35 ; \mathrm{P}<0.05)$ (figure 4$)$.

\section{Discussion}

The vast variability in the ovarian response and subsequent embryos production in MOET programs are related to many factors includes gonadotrophin sources and preparation [5-9], super-stimulation protocol [10], follicular population and its dynamics growth at the time of treatment initiation [23, 24], farm management [25], nutritional status [26, 27], genetic merit for fertility traits [28-30] and environmental conditions [31]. It has been demonstrated that FSH:LH ratio affects the ability of the ovary to respond to exogenous gonadotrophin treatment [4]. In the sense ovulation rate, number of fertilized and transferrable embryos can be improved with appropriate LH contents of gonadotrophin [32]. In the present study, three product types of commercial gonadotrophic hormones from different sources with different ratio of LH were used; Folltropin (porcine pituitary extracts contains 16\% LH), Menogon (HMG contains 50\% LH) and Fostimon (highly Purified FSH extracted from human chorionic gonadotrophin; HCG).

The rates of ovulations, fertilized ova, transferable and freezable embryos were significantly higher in Folltropin and Menogon treated cows than Fostimon group. In accordance with our findings, the ovulation rate and recovered embryos impressed by gonadotrophins dependent types [11, 33]. However, no significant differences were recorded between Folltropin and Menogon for these parameters. Similarly, Filicori [34] emphasized, no differences in the ovarian responses when HMG has been used as superovulatory hormone compared to porcine pituitary FSH extract. Moreover, Mikkola [8] concluded, the numbers of transferable embryos did not differ among dairy cows treated with Pluset (FSH:LH; 1:1) and Folltropin. Away ovulation rate and embryos production, the mean of unovulated follicles and total ovarian response were significant higher in Fostimon treated cows than Folltropin and Menogon groups. This demonstrates, highly purified rhFSH has no advantage in regard to ovulations rate and transferable embryos in comparison to Folltropin and Menogon. This result meshed with other study demonstrated that, superovulation with a recombinant bovine [35] and human FSH [36] were neither possible to increase the number of transferable embryos nor stabilize the superovulatory response. This indicates that $\mathrm{LH}$ content in FSH preparation is essential for ovarian super-stimulation. LH supplementation may increase gonadotropin sensitivity of the small follicles enhancing an increase in the number of follicles recruited and enforce follicular growth [37]. Ultimately, LH suppressing granulosa cells apoptosis and follicular atresia, and therefore multiple follicular developments are performed, even with poor ovarian response [38]. Contrary, others researchers investigated that recombinant bovine $\mathrm{FSH}$ ( $\mathrm{rbFSH}$ ) alone without exogenous LH can exert good ovulations response with high rate of fertilization and good quality embryos in both donors cows and heifers [39]. Furthermore, Kanitz [40] substantiate that, LH was not necessary for superovulatory treatment, and can be tolerated to a certain amount without negative effects on superovulatory response. Whatever the case, these Conflicts may attributable to the differences in the sources of recombinant FSH preparations. Among those who support the necessary for $\mathrm{LH}$ and who ignored the presences of LH, other team suggest that, gonadotrophin preparation, meaning FSH to LH ratio may have a significant influence on ovarian response and consequently embryo production [41]. It is noteworthy that most studies which have been involved in this section were unanimous that, a high LH content negatively affects fertilization rate and embryo quality $[5,6,8]$, whereas a low LH preparation within 15 to $20 \%$ yielded more CL, fertilized ova and transferable embryos [41]. However, the optimal FSH:LH ratio varies dependent the donors breeds [42], season of treatment [4], and gonadotrophins sources [7, 40, 41]. So, further studies are needed using Fostimon as ovarian super-stimulation with different levels of LH to determine if it was suitable for cattle MOET program.

The favorable FSH:LH ratio prepares FSH binds to its receptors producing a satisfactory induction of superstimulation and reduces the variability of the superovulatory response [43]. Contrary, high LH activities cause binding of granulosa cells followed by follicles luteinisation and receptor down regulation leading untimely premature ovulations [40, 44] and the transport of the gametes to fertilization site are associated with problems [45]. On the other side, low LH activities cause deviation in oocyte maturation, fertilization and early embryonic development [46]. However, not only, FSH:LH ratio could be affecting the ovarian response and embryos quality. It's well established, the status and the features structure of the ovaries at the time of FSH treatment initiation is included. The donor's cows with few growing antral follicles show a low ovulatory response with low number of recovered embryos [23, 24, 40]. Moreover, Wiley [47] concluded, the initiation of ovarian super-stimulation during regression phase of $\mathrm{CL}$ which associated with low level of endogenous progesterone may decrease the total number of embryos production. Several studies have been attempted to reduce FSH doses that can achieve favorable results with lowest economically costs. In the current study, irrespective the types of superovulatory hormone, generally, no significant differences were observed between doses for the means of ovulation rate. Whereas, the means of transferable and freezable embryos were significantly increased as the dose of super-stimulatory 
hormones increased. However, the types of hormones and its doses were significantly correlated with transferable embryos. Similarly, the recovered embryos and to some extent the ovulation rate showed gonadotropins types and doses-dependent pattern [7, 11, 33, 48]. The ovulation rates continued to increase as FSH doses increased beyond a certain plateau does not done, at the same time fertilization rate and transferable embryo rate remained constant throughout the doses range [7, 48, 49]. On other side, some reports have shown there is no effect of gonadotropins doses on embryo quality [50]. Anyway, the detrimental effects of high doses of gonadotrophins on embryos quality may be resulting from an excess of LH [4]. The gonadotropin receptors for LH and FSH play a central role in governing reproductive competency of fertility [51]. The granulosa cells which located within antral follicles of the ovaries expressed a limited numbers of FSH receptors proteins. These receptors varies significantly throughout follicular development and responsible for connectivity with $\mathrm{FSH}$ inducing activation and developmental growth of the ovarian follicles [52]. FSH receptors on the ovaries can do polymorphism which determines the ovarian stimulation response to exogenous FSH [53]. During super-stimulation, cows treated with low doses of FSH commensurate with the receptors numbers are showed good response to the hormonal treatment, since the sufficient numbers of FSH receptors are able to support the response. Whereas, cows administered with a high doses of FSH does not appears further response as the FSH receptors are limited [48].

The levels of AMH in the blood of cows subjected to superovulatory treatment were used as a marker to predict ovarian responses and consequently the quality of recovered embryos $[14,18,23,24]$. The study herein showed that, the correlations between AMH concentrations and ovarian response were significant positive $(\mathrm{P}<0.05)$ for $\mathrm{CL}(\mathrm{r}=0.36)$, total ovarian response $(\mathrm{P}<0.01 ; \mathrm{r}=0.80)$, transferable embryos $(\mathrm{r}=0.32)$, and freezable embryos $(\mathrm{r}=0.35)$. Similar correlations were reported by other researchers $[15,17,18$, 54-56]. AMH produced by granulosa cells of the ovarian follicles [57] and the numbers of ovarian follicles are variable across females and highly repeatable within individuals [16, 24]. Therefore, both AMH and antral follicles populations (AFP) are heritable trait $[16,17]$ can be used to predict ovarian stimulatory response [23] and the capacity of transferable embryo production [16, 17, 58]. Furthermore, Nabenishi [59] suggesting that AMH concentration during the rearing period was stable over time and individually specific, so it's useful as markers at early stage for selecting young female calves which can be used later in future as donor cows. Based on AMH concentrations of the donor's cows before super-stimulation, the means of $\mathrm{CL}$, total ovarian response, transferable and freezable embryos were significant $(\mathrm{P}<0.01)$ higher for cows group having $\mathrm{AMH} \geq 230 \mathrm{ng} / \mathrm{L}$. In agreement with our findings, low category of AMH was adopted $<200 \mathrm{ng} / \mathrm{L}$ with poor ovarian response and the high category $>400 \mathrm{ng} / \mathrm{L}$ with good response and more produce embryos in cattle $[15,18]$ and buffaloes
[60]. Similarly, Monniaux [17] determine cows with $>200 \mathrm{ng} / \mathrm{L}$ of AMH were produced more embryos than cows having $\leq 200 \mathrm{ng} / \mathrm{L}$ of AMH. Contrary, Souza [55] reported that $\mathrm{AMH}$ quartile had no effect on the percentage of transferrable or fertilized embryos. However, the differences between AMH measurements might be related to differences AMH assays, type of blood (serum or plasma) and the types of anticoagulants used to collect plasma (EDTA vs. heparin). Rico [18] observed that AMH measured in frozen blood plasma maintained with EDTA was 1.5 times higher than the same plasma samples were maintained with heparin (87 vs $123 \mathrm{pg} / \mathrm{mL}$ ). However, the current findings reveal that $\mathrm{AMH}$ concentrations before super-ovulatory treatment can be used to predict subsequent embryo productivity. In any event, it must be taken into account that AMH and AFP are varied with cattle breeds $[54,61]$ and the age progressing had negative influence on superovulatory response $[10,25]$. It appears that $\mathrm{AMH}$ inhibited the activation of primordial follicles to begin growing [62] lowering the rates of follicular atresia and avoid the premature depletion of the follicular population in the ovary [54]. Consequently, AMH works as organizing the recruitment of primordial follicles into folliculogenesis, allowing these follicles to responsiveness to FSH and undergo final maturation [57]. Low AMH concentrations are mostly associated with a developmental disorder of granulosa cells that could negatively impact the cytoplasmic maturation of oocytes producing embryos of inferior quality [63].

\section{Conclusion}

Refers to these results, Menogon with doses 600-900IU can be used as rhFSH for induction ovarian super-stimulation in dairy cow with good outcomes of embryos quality. Before super-ovulatory treatment, measurement of AMH for candidate donors cows could be helpful to select donors having AMH $>230 \mathrm{ng} / \mathrm{L}$ with good outcomes of transferable and freezable embryos. Further studies are needed using Fostimon as ovarian super-stimulation hormone concurrent with different levels of LH.

\section{Acknowledgements}

The research team is pleased to extend its sincere greetings and appreciation to Mr. Abdul Moneim Al-Awadi for his services and providing the cows needed for research work.

\section{References}

[1] Choudhary KK, Kavya KM, Jerome A, Sharma RK. Advances in reproductive biotechnologies. Vet World 2016; 9 (4): 388395.

[2] Gibbons A, Pereyra Bonnet F, Cueto MI, Catala M, Salamone DF, Gonzalez-Bulnes A. Procedure for maximizing oocyte harvest for in vitro embryo production in small ruminants. Reprod Domest Anim 2007; 42: 423-426. 
[3] Menchaca A, Vilarino M, Crispo M, de Castro T, Rubianes E. New approaches to superovulation and embryo transfer in small ruminants. Reprod Fertil Dev 2010; 22: 113-118.

[4] Mapletoft RJ, Steward KB, Gregg P, Adams A. Recent advances in the superovulation in cattle. Reprod Nutr Dev 2002; 42: 601-611.

[5] Quaresma MA, Lopes da Costa L, Robalo Silva J. Superovulation of Mertolenga cows with two FSH preparations (FSH-P and FOLLTROPIN). Rev Port Ci Vet 2003; 98 (546): 81-84.

[6] Ferré L, Bogliotti Y, Chitwood J, Kjelland M, Ross P. Hormonal follicle stimulation in Holstein cows for in vitro embryo production using sperm sorted by flow cytometry. Reprod Fert Dev 2016; 28: 248.

[7] Tasdemir U, Karasahin T, Satilmis M, Hamdi kizil S, Kaymaz M. Various FSH Administration on Superovulatory Response and Embryo Yield in Anatolian Black Heifers. Kocatepe Vet $J$ 2016; 9 (4): 322-326

[8] Mikkola M, Taponen J. Embryo yield in dairy cattle after superovulation with Folltropin or Pluset. Theriogenology 2017; 15 (88): 84-88.

[9] Giuliana Dell'Eva, Davide Bolognini, Eleonora Iacono, Barbara Merlo. Superovulation protocols for dairy cows bred with SexedULTRA ${ }^{\mathrm{TM}}$ sex - sorted semen. Reprod Dom Anim 2019; 54: 756-761.

[10] Dias FC, Khan MI, Adams GP, Sirard MA, Singh J. Granulosa cell function and oocyte competence: Super-follicles, supermoms and super-stimulation in cattle. Anim Reprod Sci 2014; 149 (1-2): 80-89.

[11] Marian O, Manuela P, Alexandru S, Alin I, Birboiu. The Effect of Epidural Administration of FSH in Bovine Superovulation Protocol. Anim Sci 2015; LVIII: 217-220.

[12] Zangirolamo AF, Morotti F, Silva NC, Sanches TK, Seneda MM. Ovarian antral follicle populations and embryo production in cattle. Proceedings of the 34rd Meeting of the Association of Embryo Transfer in Europe (AETE); Nantes, France, September 7th and 8th, 2018.

[13] Hirayama H, Naito A, Fujii T, Sugimoto M, Takedomi T, Moriyasu S, Sakai H, Kageyama S. Effects of genetic background on responses to superovulation in Japanese Black cattle. J Vet Med Sci 2019; 81 (3): 373-378.

[14] Simopoulou M, Sfakianoudis K, Antoniou N, Maziotis E, Rapani A, Bakas P, Anifandis G, Kalampokas T, Bolaris S, Pantou A, Pantos K, Koutsilieris M. Making IVF more effective through the evolution of prediction models: is prognosis the missing piece of the puzzle? Syst Biol Reprod Med 2018; 64 (5): 305-323.

[15] Keith Center, Dave Dixon, Charles Looney, Rick Rorie. AntiMullerian Hormone and Follicle Counts as Predictors of Superovulatory Response and Embryo Production in Beef Cattle. Advan Reprod Sci 2018; 6: 22-33.

[16] Monniaux D, Drouilhet L, Rico C, Estienne A, Jarrier P, Touzé JL, Sapa J, Phocas F, Dupont J, Dalbiès-Tran R et al. Regulation of antiMüllerian hormone production in domestic animals. Reprod Fert Devel 2012; 25: 1-16.

[17] Monniaux D, Barbey S, Rico C, Fabre S, Gallard Y, Larroque $\mathrm{H}$. Anti-Mullerian hormone: a predictive marker of embryo production in cattle? Reprod Fertil Dev 2010; 22: 1083-1091.

[18] Rico C, Drouilhet L, Salvetti P, Dalbiès-Tran R, Jarrier P, Touzé JL, Pillet E, Ponsart C, Fabre S, Monniaux D. Determination of anti-Müllerian hormone concentrations in blood as a tool to select Holstein donor cows for embryo production: from the laboratory to the farm. Reprod Fert Dev 2012; 24: 932-944.

[19] Cliff Lamb G, Stevenson JS, KeslerJ, Garverick HA, Brown $\mathrm{DR}$, Salfen BE. Inclusion of an intravaginal progesterone insert plus $\mathrm{GnRH}$ and prostaglandin $\mathrm{F}$ for ovulation control in postpartum suckled beef cows. J. Anim. Sci 2001; 79: 22532259.

[20] Larson JE, Lamb GC, Stevenson JS, Johnson SK, Day ML, Geary TW, Kesler DJ, DeJarnette JM, Schrick FN, DiCostanzo A, Arseneau JD. Synchronization of estrus in suckled beef cows for detected estrus and artificial insemination and timed artificial insemination using gonadotropin-releasing hormone, prostaglandin $\mathrm{F} 2 \alpha$, and progesterone (CIDR): J Anim Sci 2006; 84 (2): 332-342.

[21] Robertson I, Nelson R. Certification and identification of the embryo. In: Stringfellow DA, Seidel SM (eds), Manual of the International Embryo Transfer Society, $3^{\text {rd }}$ edition. Savoy, IL; IETS, 1998; 103-134.

[22] Bo G, Mapletoft R. Evaluation and classification of bovine embryos. Anim Reprod 2013; 54: 344-348.

[23] Singh J, Dominguez M, Jaiswal R, Adams GP. A simple ultrasound test to predict the superstimulatory response in cattle. Theriogenology 2004; 62: 227-243.

[24] Ireland JJ, Ward F, Jimenez-Krassel F, Ireland JL, Smith GW, Lonergan P, Evans AC. Follicle numbers are highly repeatable within individual animals but are inversely correlated with FSH concentrations and the proportion of good-quality embryos after ovarian stimulation in cattle. Hum Reprod 2007; 22: $1687-1695$.

[25] Silva JC, Alvarez RH, Zanenga CA, Pereira GT. Factors affecting embryo production in superovulated Nelore cattle. Anim Reprod 2009, 6 (3): 440-445.

[26] Ireland JJ, Smith GW, Scheetz D, Jimenez-Krassel F, Folger JK, Ireland JL, Mossa F, Lonergan P, Evans AC. Does size matter in females? An overview of the impact of the high variation in the ovarian reserve on ovarian function and fertility, utility of anti-Mullerian hormone as a diagnostic marker for fertility and causes of variation in the ovarian reserve in cattle. Reprod Fertil Dev 2011; 23: $1-14$.

[27] Evans AC, Mossa F, Walsh SW, Scheetz D, Jimenez-Krassel F, Ireland JL, Smith GW, Ireland JJ. Effects of maternal environment during gestation on ovarian folliculogenesis and consequences for fertility in bovine offspring. Reprod Domest Anim 2012; 47 (4): 31-37.

[28] Jaton C, Koeck A, Sargolzaei M, Malchiodi F, Price CA, Schenkel FS, Miglior F. Genetic analysis of superovulatory response of Holstein cows in Canada. J Dairy Sci 2016; 99 (5): $3612-3623$.

[29] Parker Gaddis KL, Dikmen S, Null DJ, Cole JB, Hansen PJ. Evaluation of genetic components in traits related to superovulation, in vitro fertilization, and embryo transfer in Holstein cattle. J Dairy Sci 2017; 100 (4): 2877-2891. 
[30] Moore SG, Cummins SB, Mamo S, Lonergan P, Butler ST. Genetic merit for fertility traits in Holstein cows: VI. Oocyte developmental competence and embryo development. J Dairy Sci 2019; 102 (2): 4651-4661.

[31] Palubinskas G, Z ilaitis G, Antanaitis R. Improvement of dairy cow embryo yield with low level laser irradiation. Polish $J$ Vet Sci 2017; 20 (2): 307-312.

[32] Chupin D, Combarnous Y, Procureur R. Antagonistic effect of LH in commercially available gonadotrophins. Theriogenology 1984; 25: 167.

[33] Tasdemir U, Satilmis M, Karasahin T, Hamdi Kizil S, Kaymaz M, Imai K. The Effect of Single Epidural Plus Intramusculer Injection of FSH on Superovulatory Response in Anatolian Black Cow. Ankara Üniv Vet Fak Derg 2012; 59: 211-216.

[34] Filicori M, Cognigni GE, Pocognoli P, Tabarelli C, Ferlini F, Perri T, Parmegiani L. Comparison of controlled ovarian stimulation with human menopausal gonadotropin or recombinant follicle-stimulating hormone. Fertil Steril 2003; 80 (2): 390-397.

[35] Wilson JM, Jones AL, Moore K, Looney CR, Bondioli KR. Superovulation of cattle with a recombinant-DNA bovine follicle stimulating hormone. Anim Reprod Sci 1993; 33: 71-82.

[36] Takagi M, Kim IH, Izadyar F, Hyttel P, Bevers MM, Dieleman SJ, Hendriksen PJ, Vos PL. Impaired final follicular maturation in heifer after superovulation with recombinant human FSH. Reproduction 2001; 121 (6): 941-51.

[37] Viudes-de-Castro MP, Pomares A, M. Saenz de Juano MD, Marco-Jiménez F, Vicente JS. Effect of luteinizing hormone on rabbit ovarian superstimulation and embryo developmental potential. Theriogenology 2015; 84 (3): 446-451.

[38] Hattori K, Orisaka M, Fukuda S, Tajima K, Yamazaki Y, Mizutani T, Yoshida Y. Luteinizing Hormone Facilitates Antral Follicular Maturation and Survival via Thecal Paracrine Signaling in Cattle. Endocrinology 2018; 159 (6): 2337-2347.

[39] Paulo D. Carvalho, Katherine S. Hackbart, Robb W. Bender, Giovanni M. Baez, Paul M. Fricke. Use of a single injection of long-acting recombinant bovine FSH to superovulate Holstein heifers: A preliminary study. Theriogenology 2014; 82 (3): 481-489.

[40] Kanitz W, Becker F, Schneider F, Kanitz E, Leiding C, Nohner HP, Pöhland R. Superovulation in cattle: practical aspects of gonadotropin treatment and insemination. Reprod Nutr Dev 2002; 42 (6): 587-599.

[41] Willmott N, Saunders J, Bo GA, Palasz A, Pierson RA, Mapletoft RJ. The effect of FSH/LH ratio in pituitary extracts on superovulatory response in the cow. Theriogenology 1990; 33: 347

[42] Cliff Lamb. Factors affecting an embryo transfer program. In proceedings: Applied Reproductive Strategies in Beef Cattle 2005; Lexington, Kentucky.

[43] Gonzalez A, Lussier JG, Carruthers TD, Murphy BD, Mapletoft RJ. Superovulation of beef heifers with Folltropin. A new FSH preparation containing reduced LH activity. Theriogenology 1990; 33: 519-529.

[44] Hiroshi Kishi, Yoshikazu Kitahara, Fumiharu Imai, Kohshiro
Nakao, Hiroto Suwa Expression of the gonadotropin receptors during follicular development. Reprod Med Biol 2018; 17 (1): $11-19$.

[45] Greve T, Callesen H, Hyttel P, Hoier R, Assey R. Effects of exogenous gonadotrophins in oocyte and embryo quality in cattle. Theriogenology 1995; 43: 41-50.

[46] Kumar P, Farouk SS. Luteinizing hormone and its dilemma in ovulation induction. J Hum Reprod Sci 2011; 4 (1): 2-7.

[47] Wiley C, Jahnke M, Redifer C, Gunn PJ, Dohlman T. Effects of endogenous progesterone during ovarian follicle superstimulation on embryo quality and quantity in beef cows. Theriogenology 2019; 4 (15) 129: 54-60.

[48] Ali MS, Khandoker MA, Afroz MA, Bhuiyan AK. Ovarian Response to Different Dose Levels of Follicle Stimulating Hormone (FSH) in Different Genotypes of Bangladeshi Cattle. Asian Australas J Anim Sci 2012; 25 (1): 52-58.

[49] Alkemade SJ, Murphy BD, Mapletoft RJ. Superovulation in the cow: Effects of biological activity of gonadotropins, Proc 12th Ann. Conv. AETA, Portland, Maine 1993.

[50] Barati F, Niasari-Naslaji A, Bolourchi M, Sarhaddi F, Razavi K, Naghzali E, Thatcher WW. 2006. Superovulatory response of Sistani cattle to three different doses of FSH during winter and summer. Theriogenology 2006; 66 (5): 1149-55.

[51] Anderson RC, Newton CL, Anderson RA, Millar RP. Gonadotropins and their analogs: Current and Potential Clinical Applications. Endocr Rev 2018; 39 (6): 911-937.

[52] Borgbo T, Klučková H, Macek M, Chrudimska J, Kristensen SG, Hansen LL, Andersen CY. The Common FollicleStimulating Hormone Receptor (FSHR) Promoter Polymorphism FSHR -29G > A Affects Androgen Production in Normal Human Small Antral Follicles. Front Endocr (Lausanne) 2017; 2 (8): 122.

[53] Laven JS. Follicle Stimulating Hormone Receptor (FSHR) Polymorphisms and Polycystic Ovary Syndrome (PCOS). Front Endocr (Lausanne) 2019; 12 (10): 23.

[54] Batista EO, Macedo GG, Sala RV, Ortolan MDDV, Sá Filho MF, Del Valle TA, Jesus EF, Lopes RN, Rennó FP, Baruselli PS. Plasma antimullerian hormone as a predictor of ovarian antral follicular population in Bos indicus (Nelore) and Bos taurus (Holstein) heifers. Reprod Domest Anim 2014; 49: 448-452.

[55] Souza AH, Carvalho PD, Rozner AE, Vieira LM, Hackbart KS, Bender RW, Dresch AR, Verstegen JP, Shaver RD, Wiltbank MC. Relationship between circulating anti-Müllerian hormone (AMH) and superovulatory response of high-producing dairy cows. $J$ Dairy Sci 2015; 98: 169-178.

[56] Hirayama H., Naito A, Fukuda S, Fujii T, Asada M, Inaba Y, Takedomi T, Kawamata M, Moriyasu S, Kageyama S. Longterm changes in plasma anti-Müllerian hormone concentration and the relationship with superovulatory response in Japanese Black cattle. J Reprod Dev 2017; 63: 95-100.

[57] Visser JA, de Jong FH, Laven JS, Themmen AP. AntiMullerian hormone: a new marker for ovarian function. Reprod 2006; 131: 1-9.

[58] Baruselli PS, Batista EO, Vieira LM, Souza AH. Relationship between follicle population, AMH concentration and fertility in cattle. Anim Reprod 2015; 12 (3): 487-497. 
[59] Nabenishi H, Kitahara G, Takagi S, Osawa T. Relationship between plasma anti-Müllerian hormone concentrations during the rearing period and subsequent embryo productivity in Japanese black cattle. Domest Anim Endocr 2017; 60: 1924.

[60] Redhead AK, Siew N, Lambie N, Carnarvon D, Knights M. The relationship between circulating concentration of AMH and $\mathrm{LH}$ content in the follicle stimulating hormone (FSH) preparations on follicular growth and ovulatory response to superovulation in water buffaloes. Anim Reprod Sci 2018; 188 (1): 66-73.

[61] Stojsin-Carter A, Mahboubi K, Costa NN, Gillis DJ, Carter TF, Neal MS, Miranda MS, Ohashi OM, Favetta LA, King WA. Systemic and local anti-Mullerian hormone reflects differences in the reproduction potential of Zebu and European type cattle. Anim Reprod Sci 2016; 167: 51-58.
[62] Visser JA, Themme AP. Role of anti-Müllerian hormone and bone morphogenetic proteins in the regulation of $\mathrm{FSH}$ sensitivity. Mol Cell Endocr 2014; 382 (1): 460-465.

[63] Silberstein T, MacLaughlin DT, Shai I, Trimarchi JR, Lambert-Messerlian G, Seifer DB, Keefe D, Blazar AS. Müllerian inhibiting substance levels at the time of HCG administration in IVF cycles predict both ovarian reserve and embryo morphology. Hum reprod 2006; 21: 159-163. European type cattle. Animal Reproduction Science 167, 5158. STOJSIN-CARTER A., MAHBOUBI K., COSTA N. N., GILLIS D. J., CARTER T. F., NEATakagi M, Kim IH, Izadyar F, Hyttel P, Bevers MM, Dieleman SJ, Hendriksen PJ, Vos PL. Impaired final follicular maturation in heifer after superovulation with recombinant human FSH. Reproduction 2001; 121 (6): 941-51. 